\title{
Waqf Corporate Role to Enhance the Social Entrepreneurship in the Egyptian Community: Problems and Remedies
}

\author{
Wael Omran Aly \\ Associated Professor of Public Administration \\ High Institute of Computer Sciences and Information Systems \\ New Cairo Academy, Egypt \\ Email:wael.omran@ymail.com
}

Received: November 17, 2016 Accepted: December 07, 2016 Published: December 31, 2016

doi:10.5296/jpag.v6i4.10504 URL: http://dx.doi.org/10.5296/jpag.v6i4.10504

\begin{abstract}
For decades, Egypt -as many developing counties-suffers from various social issues as poverty, illiteracy and the decline of public service provision as healthcare, education, potable water and sewage. In spite of all the consecutive government efforts to confront such social dilemmas, the constituents of different locality in Egypt still feel the discrepancy and decay of quality for many social services proposed by the government.

In fact, many challenges are hindering the government strategic path to overcome such social issues as the scarcity of financial and physical resources, deplorable bureaucracy crippled by red tapes, lack of competent human resources, escalated number of population and embedded corruption. Thereby, the people whined from social injustice due to the government failure in realizing a just national wealth distribution.

Hence, social entrepreneurship emerged-from the twentieth century endings- as an alternate option to resolve inadequate government performance and to improve the quality and the delivery of social services. Whereby, this can be realized by mobilizing personal properties to be allocated to public affairs in the context of people cooperation and voluntary participation values. Such process of social entrepreneurship had to take place within an entity/corporation -as non-governmental organizations NGOs- (social entrepreneur) able to manage its activities effectively realizing an adequate model of actions within the organization (intrapreneurship /internal entrepreneurship).
\end{abstract}


This paper, therefore, explores, discusses and analyzes the role of waqf corporate as a good example for social entrepreneurs who have played a significant role of providing opportunities in sharing the government's fiscal needs and improving the communities and nation welfare throughout history in many countries. Waqf corporate has a potential to become one of the effective tools regarding the socioeconomic realm in the Egyptian community; whereby it can benefit the community in term of education, health care, national security, social justice, transportation facilities, basic infrastructure, foods and job opportunities.

Keywords: Corporate waqf, Social entrepreneurship, Intrapreneurship, Egyptian community.

\section{Introduction}

For many years, the Egyptian government failed to eliminate the deprivation and realize its desired development goals; because of the budget limitations and private sectors lack of desire in pursuing social issues to fill the gap between the government actual performance and people needs and aspirations. Whereby the private sector activities in the realm of the market is highly profit oriented and are based on the criteria of economic rationality and they are seeking for their own personal benefits.

Therefore, social entrepreneurship inside the widespread Participation frame work via organized groups of people and NGOs is the finishing cycle that can bridge the gap between the federal government and market/personal sector in Egypt. The Philosophy of the charity institutions and NGOs existence, as well as the waqf corporate, is utilizing the capacity of voluntary participation by way of all society members to pervade the curb strata of the group; to resolve their social issues in various realms (Austin, Stevenson\& others, 2006). Then, the principal persona of social entrepreneurship moves is to do whatever with goodwill and philanthropically intentions in pursuing social ambitions for the good of the community (Weerawardena, 2006).

Thus, the research problem hereby is the disability of government organizations and private sectors corporations in Egypt to eliminate solely the social deprivation in the community with the context of many environmental challenges as the lack of financial physical, human, technological resources and capabilities. Then, in order to overcome such dilemma; the government had to embrace the waqf corporate as a social entrepreneur tool, able to mobilize and reallocate voluntary the personal properties to realize effectively various social goals concerning public interests via innovative processing (intrapreneurship). Consequently, it will yield the intended social welfare of the community

Hence, in this paper the researcher strives - via analytical qualitative methodology- to find the answer for the following research question "how the waqf corporate can be able to enhance the social entrepreneurship necessary to realize social welfare at the Egyptian community?". Therefore, the researcher aims firstly to shed light on social entrepreneurship concept and significance. Secondly, to interpret social intrapreneurship concept and the principles of effective social entrepreneurship corporate. Thirdly, to identify the waqf 
corporate concept and principles. Fourthly, to describe the nature and the problems facing the work of waqf corporate in the Egyptian community. Finally, to prescribe the different remedies necessary to convert the conventional waqf corporate in Egypt into effective social entrepreneur able to realize effectively various social goals and societal values via innovative processing management (intrapreneurship).

\section{Social Entrepreneurship Concept and Significance}

Entrepreneurship as a term is usually linked to private sector business activity, more particularly small and moderated enterprises (SMEs). Public, private and NGOs sectors are not, however, disconnected areas in the realm of economy with no impact on each other, but interlinked in many different ways. Entrepreneurship research today seems to be concentrating on different kinds of settings, e.g. SMEs, creation and growth of firms, innovative social services of public service and NGOs, disregarding the conceptual domain of entrepreneurship (Shane \& Venkataraman, 2000).

\subsection{Social Entrepreneurship Concept}

Entrepreneurship can be defined as perceptiveness to change and the entrepreneur as one who always searches for change, responds to it, and exploits it as an opportunity (Drucker, 1985).Therefore, the entrepreneur had to be innovative and sees changes to his work. Entrepreneurial behavior, however, should not be limited to only the private sector as public organizations and NGOs operate with limited resources, and need to find creative solutions to continue the provision of social services in order to respond to the increased demands of the constituents. Then, an entrepreneur can be identified as one who uses resources in new ways to maximize productivity and effectiveness. In this view, entrepreneurs are those leaders who lead to success in their organizations (Osborne \& Gaebler, 1992).

Even though there is no great theory of entrepreneurship, the concept of entrepreneurship is based on entrepreneurial opportunities, without entrepreneurial opportunities there is no entrepreneurship. Entrepreneurship is a process of becoming, not a static phenomenon. The change involved usually takes place in quantum jumps, being a holistic process in which existing stability disappears (Bygrave, 1989). Therefore, entrepreneurship is about identifying opportunities, creatively breaking patterns, taking and managing risk, organizing and coordinating resources. Entrepreneurship integrates seeing (vision) and doing (action). Then, entrepreneurs are "the dreamers who do" (Pinchot, 1985).

Entrepreneurship pointed out to those who have been looking for better ways to do works done, and with experiencing Economic development as a result. Entrepreneurs with optimum use of resources and limited facilities offered more, productivity and efficiency act that it has a remarkable and more exact value-added (Landström, 1998). They always are in search for change, smart reaction to the changes and use the maximum benefit form changes. In entrepreneurship Literature, in addition to the commercial entrepreneurship which is more business and commerce oriented and taking the risk is their concern to achieve the profitability goals; social entrepreneurship is as a complementary to business entrepreneurship, have a special position in social development literature (R. Lalitha S. 
Fernando, 2005).

The term "social entrepreneurship" is relatively new, but it builds upon centuries of transformative leadership. Social entrepreneurs are people or organizations that use economic and technological innovation to achieve social goals. They use entrepreneurial skills to create organizations that, instead of seeking profit, pursue a more just and humane society (Noya, 2009). Social entrepreneurs are individuals with innovative solutions to society's most pressing social problems. They are ambitious and persistent in tackling major social issues and offering new ideas for wide-scale change. Social entrepreneurs find what is not working and solve the problem by changing the system, spreading the solution, and persuading entire societies to move indifferent directions (Slađana Brajević \& others, 2015). Social entrepreneurs create new organizations, new markets, and new ways of thinking and behaving in solidarity with poor communities to provide basic services, such as renewable energy, clean water, health care technologies, education, and access to financial services. Social entrepreneurs (SEs) devises highly affordable products and services that can be bought by people living on a few sum of money a day, and creates businesses that can distribute these to poor communities (Austin, Stevenson \& others,2006).

This range of organization types shows the range of organizations working to create change and there are many. It's also very limiting. Considering the landscape as "charity vs. company" or "social enterprise vs. social business" cloaks the wider movement that sees business and finance as a force for good. Debates have been held on positioning social entrepreneurship within one sector (non-profit sector), or in the sphere of cross-sectorial activities. It means disregarding the idea that all businesses have an impact. Some have overwhelmingly positive impacts, some have overwhelmingly negative impacts, and many fall somewhere between the two (Gliedt, T. \& others, 2007).

The nature of Social entrepreneurship is the cooperative activities such as the philanthropically activities, charity, benevolence, and sense of responsibility for the problems of the vulnerable and deprived classes of the society (Dees, j.G., 1998). The necessity for social entrepreneurship -as NGOs, grassroots organizations and corporate waqf- in modern society, that is revealed today, as a direct result for government and business institutions' failure to solve solely the social issues, today society is deadlock of capitalist system which has emphasis on personal profitability and ignoring the rights and needs of vulnerable classes, caused the added severity of poverty and deprivation and increase the gap between classes in the society(Habibollah Salarzehi \& others, 2010).

Hence, the essence of social entrepreneurship is an innovative voluntarily and the kind of friendship with a combination of good will. These kinds of entrepreneurs give services to human being aim to get an inner satisfaction. Social entrepreneurship is a process whereby individuals and groups and social sectors working voluntary in order to produce value by 
using remained social assets and opportunities (Miri, 2006). In societies people gather together and get along to have cooperation and bilateral cooperation in order to solve social issues. Social capital on the base of trust has been created to that extant in which they can create long lasting capacity for dealing with issues. Social entrepreneurship is the innovation for the problems and social issues. Social entrepreneurs normally use the innovative measures (intrapreneurship) within their organizations to create an effective mechanism of social security, enabling them to mobilize efficiently necessary resources to deal with social issues (Alvord \&Brown, 2004).

\subsection{Social entrepreneurship corporate effectiveness}

The social entrepreneurship organization can be considered effective; if the following criteria as innovation, proactiveness and risk handling can be realized as follows (Fakhrul Anwar Zainol \& others, 2014; Barlett, d. \& others, 2002):

\subsubsection{Innovation in achieving mission and managing the financial resources:} Being an organization with a mission to infuse social value in the community. Whereby it is fully incorporated with societal and religious values that emphasize on the hereafter reward for those who did well to others in their life. Meanwhile, there are often new techniques used by the organization to manage its finance efficiently in the context of modern economy, accounting and auditing principles.

\subsubsection{Proactiveness in achieving mission and managing the financial resources:} The entrepreneurship organization must show its proactiveness by showing their commitment through continuity of their activities. The members of the organization are provided with constant business opportunities so that they can succeed. Also, all of the members are well aware of the concept of giving away; entrepreneurship organization is proactively encouraging their members to fund their activities. The fund obtained has managed to cover the expenses of the organization without it having to beg other organizations for extra fund.

\subsubsection{Risk taking in achieving mission and managing the financial resources:} The entrepreneurship organization had to be less risk in handling their members because all of them are aware of its endeavors. The members know what they are going to be involved with and also about what the organization exact mission is. This is all due to early explanation by the organization management board to make the members understand the core values of the organization activities. Also, entrepreneurship organizations had to avoid any risk to become financially efficient. As their expenses and sources has to be unlimited. They could ask fund from willing members and utilize it for the organization expense. They do not have to worry about low fund because all of their members who are infused with the value of charity will surely help the organization to run smoothly risk free. 


\section{3- Social intrapreneurship concept and effectiveness principles}

Social intrapreneurship or social internal entrepreneurship is often described as something that performs the role of external social entrepreneurship within the organization (Sadler, 2000). There are similarities between external and internal entrepreneurship. For example, the internal entrepreneur, like the external, enacts new opportunities and is dependent on resources. Directly transferring knowledge of entrepreneurship in order to better understand internal entrepreneurship, however, is problematic (Burgelman, 1985).

\subsection{Social intrapreneurship concept}

Intrapreneurship processes take places within an established organization with organizational structures and procedures such as existing resource distribution routines, principles of decision making, and fixed structures (Luchsinger \& Bagby, 1987; Molina \& Callahan, 2009). Moreover, external entrepreneurs have much more personal control over the project's destiny, while risking private capital (Morris, Davis \& Allen, 1994). The risk capital of internal entrepreneurs belongs to the organization employees, while they are risking their own careers.

In several studies, it emerges that intrapreneurship is an important issue for every organization (Antoncic \& Hisrich, 2003; Wunderer, 2001). Intrapreneurship is an engine in the self-renewal and efficiency gains of organizations (Diefenbach, 2011; Lowndes, 2005). The relatively limited research concerning internal entrepreneurship in the public sector and nonprofit sector -as NGOs and waqf corporate- results in that the processes of realizing and transferring innovative projects into a permanent operation have not been to any great extent (Antoncic, 2001). Intrapreneurship has a lot in common with project management. When something new and unproven is put into practice in the public and nonprofit sector, intrapreneurship is usually defined as a project (Löfström, 2010); or a temporary organization, outside regular operations and formal procedures (Engwall \& Westling, 2004). Both, intrapreneurship and project management include implementing ideas and responding to uncertainty originating from the local environment.

Hence, social intrapreneurship is a concept closely related to social entrepreneurship emphasizing the entrepreneurial process (entrepreneurs carry out new combinations) and innovativeness (Guth \& Ginsberg 1990). The intrapreneur acts like an entrepreneur in realizing his own ideas without being the owner of the enterprise (Cunningham \& Lischeron, 1991). Social intrapreneurship is here defined to mean entrepreneurial way of action in an existing entrepreneurship organization - more specifically, in a public or nonprofit organization. The basis of social intrapreneurship is recognizing an opportunity, exploiting it and trusting that exploiting an opportunity in a new way that deviates from previous practice will succeed and support the realization of the organization's social aims (Heinonen, 1999b). 


\subsection{Social intrapreneurship effectiveness principles}

Since intrapreneurship is a collective action from beginning to end which it is less likely that one member will single-handedly abuse power and resources. Mack et al. also point out that the key to successful innovation is a local focus and a group decision-making process, which stress consultation and cooperation between the participants. However, the fact that, even within an internal entrepreneurship team, one person is usually in charge (Pinchot \& Pellman, 1999).Most teams are led by one intrapreneur, but all the members of the team can be called intrapreneurs as long as each understands the whole dream and is continually working to find better ways to make team can be called intrapreneurs as long as each understands the whole dream and is continually working to find better ways to make it happen. Therefore, many managerial and organizational prerequisites had to take place to ensure the ongoing effectiveness of Social intrapreneurship as follows:

3.2.1 Organizational and management support: The internal entrepreneurship team will need to find people in the organization who support and champion the idea, as well as actively engage in protecting it (Barlett \& Dibben, 2002; Sundin \& Tillmar, 2008). Proceeding with a new idea involves direct costs; money needs to be available to allow it to proceed (Birkinshaw, 2000; Chisholm, 1987). Support can assume many different forms, e.g. support from higher-level managers (i.e. promoting behavior), work discretion (the freedom to decide how to carry workout), rewards/reinforcement systems, resource availability, and management systems (Diefenbach, 2011).

3.2.2 Administrative linkages: The management system thus needs to secure continuous information concerning innovative projects. The effective and visible communication channels have to be established in order to report information to top management and other partners in the organization about the ways in which strategic objectives are being set, how resources allocation is being managed, and how relationships are being determined (Burgelman,1985).

3.2.3 Organization culture: it has an influence on intrapreneurship by creating a basis for growth. Security and trust as the basic assumptions of the organization create a favorable ground for the emergence of intrapreneurship. When people in community activity can rely on the fact, that the fundaments of the organization are secure, the commitment of the employees to the development of themselves and the unit will improve. Building up and developing a common target and an ambitious target-orientation in an atmosphere of trust; is necessary to make every employee understand his own role in the whole, which will improve the prerequisites of intrapreneurship (MacMillan 1986).

3.2.4 Organization Strategy: it directs organizational activity, because it usually includes the activity area of an organization (targeted constituency), central environmental factors, on which the success of the organization is built and the aims, which the organization strives to achieve (Day, 1990). The strategies of the entrepreneur organization had to be complete, aggregated and clear from the point of view of directing activities. The strategies of the organization had to be formed specifically as an expression of will of the targeted community as a whole, which the organization strive to implement efficiently and effectively within the 
limits of their capabilities and resources.

3.2.5 Organization structure: on the basis of the units studied, the natural co-operation to achieve the common aims during the daily tasks of the employees improves the possibilities for intrapreneurship. Flat structure, flexibility and loose task definitions make the daily participation and co-operation possible. Development and change are investments in the future, which is why the time reserved for development work promotes intrapreneurship. A central issue is also, how intrapreneurship is encouraged (Alpkan, L., \& others, 2010).

It is valuable to note hereby, that Organizational performance and intrapreneurship are linked to each other. Intrapreneurship, firstly, improves the performance (both economic and non-economic) of the organization (Pearce \& others, 1997). The relation works also to the opposite direction: the success of the organization influences intrapreneurship. It is easier for a successful organization to exploit opportunities, to innovate and change when it has the necessary resources at its disposal (Westrup, 2013). However, it was noticed, that adequate resources and success promote intrapreneurship; correspondingly, scarce resources and negative feedback curb it.

\section{4- Waqf corporate: concept and significance}

Waqf is as Islamic charity groundwork for the realization of pursuits by way of the property and finance that allotted to legal basis. Waqf as a base thorough which the continuance of alms is feasible were traditional in historic between different international locations, but in Islam, given that of emphasize in Quran and traditions to support the weak and poor people; it has made charity and devoting more principal. Although in other religions and between the United Nations the commit Property had been usual, however Waqf in Islam having a special quandary and has emphasizes in devout teachings to move that as a way to appeal to God's delight (Anjavinejad \& Eami, 2005). Islamic civilization have had a gigantic result on the valuation of Waqf and lots of non-Muslim nations have obeyed the Waqf tradition in Islam and have taken a long step in the area of property dedicated to objectives for humanitarian and progress. At the moment, lots of devout and countless charity foundation, belonged to properties advantages, are just active in the United States of America and several European countries. Oxford school nearly has been introduced as mannequin of Waqf headquartered on Islamic basis dedicated (Kahf, 1999).

The difference between charity and Waqf is that charity normally is normal motion and entails phase charitable contribution, at the same time Waqf is voluntary motion that the owners of the capital, dedicating permanently part of their private property for charity routine therefore, Waqf is a style of permanent and continuous doing good oriented corporate, Waqf much like other activities is within the realm of voluntary charity. Functions pursuits and earnings of Waqf can be spent on educational institutions, orphan house, utilization of mosques and different public charity (Sadeq, 2002). Then, the Waqf is a foundation fashioned through voluntary donation. The term waqf literally approach forbidding motion, transport, or exchange of anything, as a result the 'basis' have to have perpetuity. Property owners can 
form awqaf, by means of dedicating the revenue of the complete property or a section of the estate, to a few charitable ends throughout the property's existence (Raissouni, 2001).

In Islamic countries there are a lot of projects that are operated by way of benefices and assets of the Waqf from good perspective. The results of Waqf will also be expressed to humanitarian tasks, cultural, financial, health, education and training, and much other social welfare (Habibollah Salarzehi \& others, 2010). For example Waqf of the spring water for public consumption, building houses for deprived, the position free situation for an needy poor travelers, keeping bridges, organize the funeral of the dead who have been poor, serving to the handicapped, financing the wedding young folks in want, and protection orphanage and the homes of the needy aging people by using the Waqf property and assets. There are a lot of instances of benefices use in the fields of well-being, therapy, education and training .For instance hospitals and medical rescue teams who are visiting village to village are managed by means of the property and belongings of the Waqf (Krafess, 2005).

Waqf much like other pursuits is within the realm of voluntary charity. Functions ambitions and earnings of Waqf will also be spent on educational institutions, orphan house, utilization of mosques and public charity. Then, three types of Waqf in Islam will also be identified as follows: (Sadeq, 2002; Habibollah Salarzehi \& others, 2010).

1. Religious Waqf: nearly all of mosques within the Islamic world is form of devout Waqf that they've been situated by good-that means. Moreover the property has been allocated for mosques and religious faculties are type of endowments.

2. Philanthropic Waqf: in humanitarian Waqf, advantages are allotted to public for the aid poor and also promote social events. For example the library, educational centers, healthcare, animals care, takes care of environment, development events of the green space, and roads are style of benefits.

3. Household Waqf: it pointed the Waqf from the parents to kids and heirs; so that the additional income can be spent for poor people (Kahf, 2002).

Hence, Waqf corporate can play an important role in the community to enhance the social entrepreneurship; if it adopts the intrapreneurship principles -as it mentioned at the previous section- to create the suitable governance able to make the corporate equipped with innovation, proactiveness and risk handling techniques necessary to pervade the different strata of the community and responding effectively to their arisen needs and wants. 


\section{5- Waqf corporate in the Egyptian community: insights and problems}

Since Islam has shined on Egypt; it knew the Waqf corporate. Since then the size of Waqf institutes have expanded till that in the thirteenth of the twentieth century $40 \%$ of the agricultural lands were Waqf. In addition to this many real estate buildings were suspended as waqf corporate for many alms expenses as for Islamic missionary, education, healthcare, potable water, social care, orphanage, animals care and etc.... (Omar, 2004)

Therefore, the law no. 48 for year 1946 had been issued to organize the vast development in Waqf philanthropic activities in Egypt. According to such law the minister of awqaf became the responsible to oversee the waqf corporate and manage its activities via the supreme council of awqaf. The owner of Waqf and his heirs can manage its activities under the supervision of ministry of awqaf. In 1971 the law no. 80 had been issued; whereby the Egyptian awqaf apparatus is established (El Weeshey, 2002), to take over the responsibility of managing the waqf corporate with the direct supervision of minister of awqaf (see fig.1).

Consequently, the Egyptian awqaf apparatus has begun since the eighteenth to invest the financial and physical assets - approximately they worth billions of pounds- of different corporate waqf in different economical domains as industry, agriculture, real estate, financial bonds and stocks in order to maintain the waqf assets in good conditions for next generations; and to engender revenues used as funds to serve social goals critical for the welfare of the community (Omar, 2004).Thereby, waqf corporate under the supervision of Egyptian awqaf apparatus executes many development activities in Egypt based on invested sources and dedicated assets; as follows (Ameen, 1980; Zaqzouq, 2000):

1. Training courses such as primary schools and secondary schools and also established colleges and higher education institutes (for example in Egypt thousands of educational institution on the basis of Waqf have been established under the academic supervision of Azhar institution).

2. Building Houses and taking care of orphan centers which kept the children and people without shelter and give those living facilities and free education.

3. Almost the majority of the mosques in Egypt are as Cultural and public Centers offer social services to Muslims and thousand mosques have been established through Waqf and educational activities in the mosques would be presented for free. In addition in rural Egypt, mosques and Islamic teachings educational schools would be managed on the basis of benefices.

4. Clinics and health centers are examples of the charity activities based on sources of benefices.

5. Dedicated stores and commercial centers which are source of income opportunities and providing financial sources for public work and charity project.

6. Other sources such as finance and residential property, agricultural, stock companies and factories. 


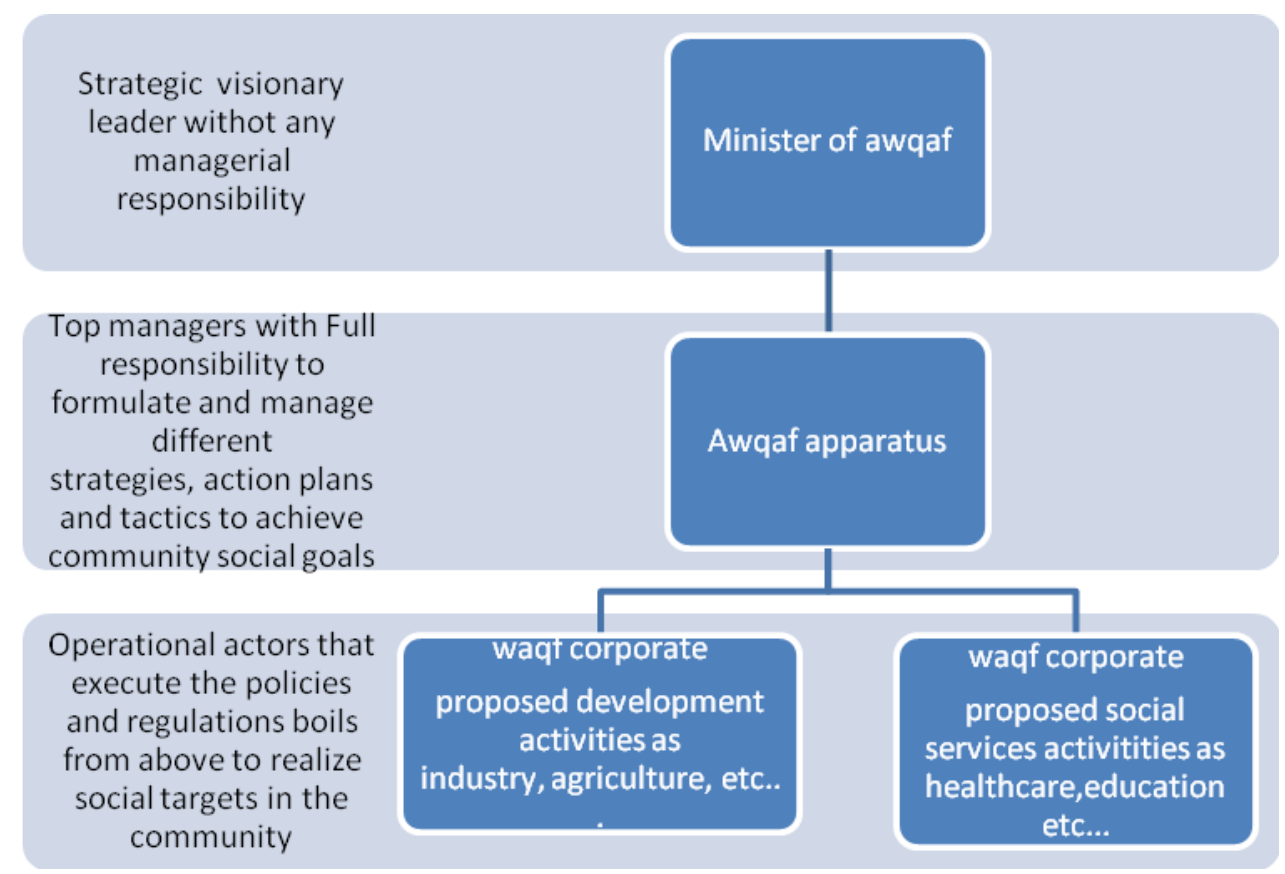

Fig.1: Egyptian awqaf management structure

In spite of all the previous efforts exerted by the Egyptian awqaf apparatus as a potential social entrepreneur in the society; it was not enough to narrow the gap between the poor and the rich or to alleviate the failure of government in delivering suitable social service to the indigenous. This matter is due to some problems that hinder the efforts of waqf corporate to enhance the social entrepreneurship for the sake of the community. These problems are as follows: (El Weeshey, 2002; Khoulousy, 2002; Omar, 2004)

Legal problems: Waqf corporate is managed in the context of various valid laws as law no.48 for year 1946 and its several amendments, and law no.80 for year 1971 and its several amendments over several years. Such complicated legal environment cripples the flow of activities of waqf corporate whereby the majority of these laws are contradicted and not responding to changing circumstances of the community environment.

Managerial and organizational problems: the Egyptian awqaf apparatus as it is the central organization oversees all the corporate Waqf in Egypt, suffers from huge deplorable structure featured by rigidity, centralization, crippled red tapes, paralyzed communication channels and untrained mediocre employees suffering from low wage as well as low morality. Such apathetic bureaucracy hinders any attempt for quick responsiveness and innovation regarding the community social issues. Meanwhile, the leadership style adopted in this organization 
didn't have any strategic vision. It is also authoritarian regarding its management manifestations, it means not supportive for participative decision making process. So, the managerial motto in such bureaucracy discourage team working and cooperation; whereby the organizational culture espoused hampers knowledge sharing, employee empowerment, visibility and creativity. Then, the Egyptian awqaf apparatus is apparently a model for bad governance; whereby the intrapreneurship principles necessary to create effective social entrepreneurship, are absent in such organization.

Economic and financial problems: Despite that the Egyptian awqaf apparatus has begun since the eighteenth of the twentieth century to invest efficiently the financial and physical assets of different corporate waqf in different economical domains to maintain the economic development; but these investment methods were very limited. Whereby the majority of corporate waqf assets were invested conventionally, without any strategic economic vision; as in bank savings with interests, by give away some of this waqf assets to other beneficiary in different forms as leasing, selling and concession below the market value of these assets. Consequently, the net income of the corporate waqf investment was very inferior; even in some years didn't overpass $1 \%$. This dilemma is due to some unqualified employees within the Egyptian awqaf apparatus that didn't have in fact any economical or financial competency to run the waqf corporate assets efficiently.

Social and cultural problems: It is apparent that the majority of waqf corporate in Egypt are from the heritage of ancestors; whereby the current generation didn't contribute enough in creating new Waqf corporate as the community suffers from lack of awareness regarding the idea of Waqf corporate, its activities and benefits. Whereby the government, mass communication institutions and civil society organizations didn't promote or embrace the notion of waqf corporate and its vital role as social entrepreneur. Thereby, the societal culture revolves around that waqf corporate is the government responsibility only.

Embedded corruption: The lack of transparency and community awareness about waqf corporate activities revenues' and expenses'; whereby the Egyptian awqaf apparatus balance sheet didn't differentiate between its proper expenses and revenues and such of the waqf corporate under its supervision. This matter enables some corrupted employees to abuse their authorities to realize personal benefits. Thus, the waqf corporate assets will be eradicated overtime; and the notion of waqf corporate itself becomes useless or evens a burden on the community.

\section{6- Proposed remedies to confront the Egyptian waqf corporate problems}

The Waqf corporate is crippled by various problems -as it is mentioned previously- that impede its path to lead the social entrepreneurship in the Egyptian community. Therefore, the government had to adopt some remedy indices relying on new public management principles (NPM) and good governance principles as transparency, participation, result based management, accountability, law enforcement and justice, and efficient financial performance, and social intrapreneurship principles - mentioned previously- to overcome such problems; 
and reform the Egyptian awqaf apparatus to revive the social role of waqf corporate in the community. Such proposed remedy indices are as follows (see fig. 2):

\subsection{Managerial and organizational indices}

The Egyptian awqaf apparatus had to be deregulated; in order to convert such conventional organization featured with a rigid centralized structure into an intrapreneurship organization able to play a vital social entrepreneurship role in the community. The intended managerial and organizational reform key factors can be as follows: (Osborne \& Gaebler, 1992; Larbi, 1999; Pollitt, 1994; Westrup, 2013)

- The need for strategic leaders (in any respect organizational levels within the awqaf apparatus) to ensure that the strategies of the organization had to be complete, aggregated and clear from the point of view of directing social activities. As the strategies of the organization had to be formed specifically as an expression of the will of the targeted community as a whole, which the organization strive to implement them efficiently and effectively within the limits of their capabilities and resources. Then, such managerial leader had to adopt the strategic administration methodology and to share their strategic visions with all the stakeholders (sharing leaders).

- A change in the focus of management from inputs and methods toward outputs and outcomes, consequently, adopting the results based management is a necessity; whereby a stress on dimensions and quantifications is critical. Primarily in the type of programs of performance indicators, to ensure that the activities of the organization will pervade to the community and reach its social aims.

- The creation of a learning structure with suitable size that is flat, flexible and adaptable to changes in the external atmosphere. This constitution should ease the creation, maintenance and sharing of useful knowledge and capabilities that can be used inside and crosswise organizational restrictions. In other words, a learning organization had to be created. Then, the favorite of lean/flat and impartial organizational types: decentralization and empowerment.

- The establishment of effective channels of communication is a must; to secure continuous information concerning innovative projects, and to report information to top management about the ways in which strategic objectives are being set and also to all stakeholders whether they are internal or external. Moreover, how resources allocation is being managed, and how relationships are being determined (Burgelman, 1985).

-The adoption of E. government applications to simplify the procurement procedures of the entire form of social services; to establish a fast responsiveness to folks needs and wants.

- Adopting lean approach to social services management; by means of sustaining an effective worth move of value-delivered activities to fulfill citizens' desires in high quality, minimum fee and minimal time. 


\section{Macrothink}

Journal of Public Administration and Governance

ISSN 2161-7104

2016, Vol. 6, No. 4

- Embracing an organizational culture and a strong code of ethics espousing the values of security and trust as the basic assumptions of the organization create a favorable ground for the emergence of intrapreneurship. Whereby the fundaments of the organization are secure, the commitment of the employees to the development of themselves and the unit will improve. Building up and developing a common target and an ambitious target-orientation in an atmosphere of trust is necessary to make every employee understand his own role in the whole, which will improve the prerequisites of intrapreneurship.

-Adjusting the staffing programs, coaching and human development guides to fortify job effectiveness, efficiency and employees' satisfaction. So, the correct individual who is ready, and persuaded to realize the intrapreneurship principles and create an effective social entrepreneurship corporate; will fill into the proper submit.

- Managerial leaders' commitment and support to use intrapreneurship standards to create an effective social entrepreneurship corporate; will facilitate the execution of organizational intrapreneurship policies and procedures; and likewise will decrease the staff' resistance. Then, support from higher-level managers can have many forms as promoting behavior, work discretion (the freedom to decide how to carry workout), rewards/reinforcement systems, resource availability, and management systems.

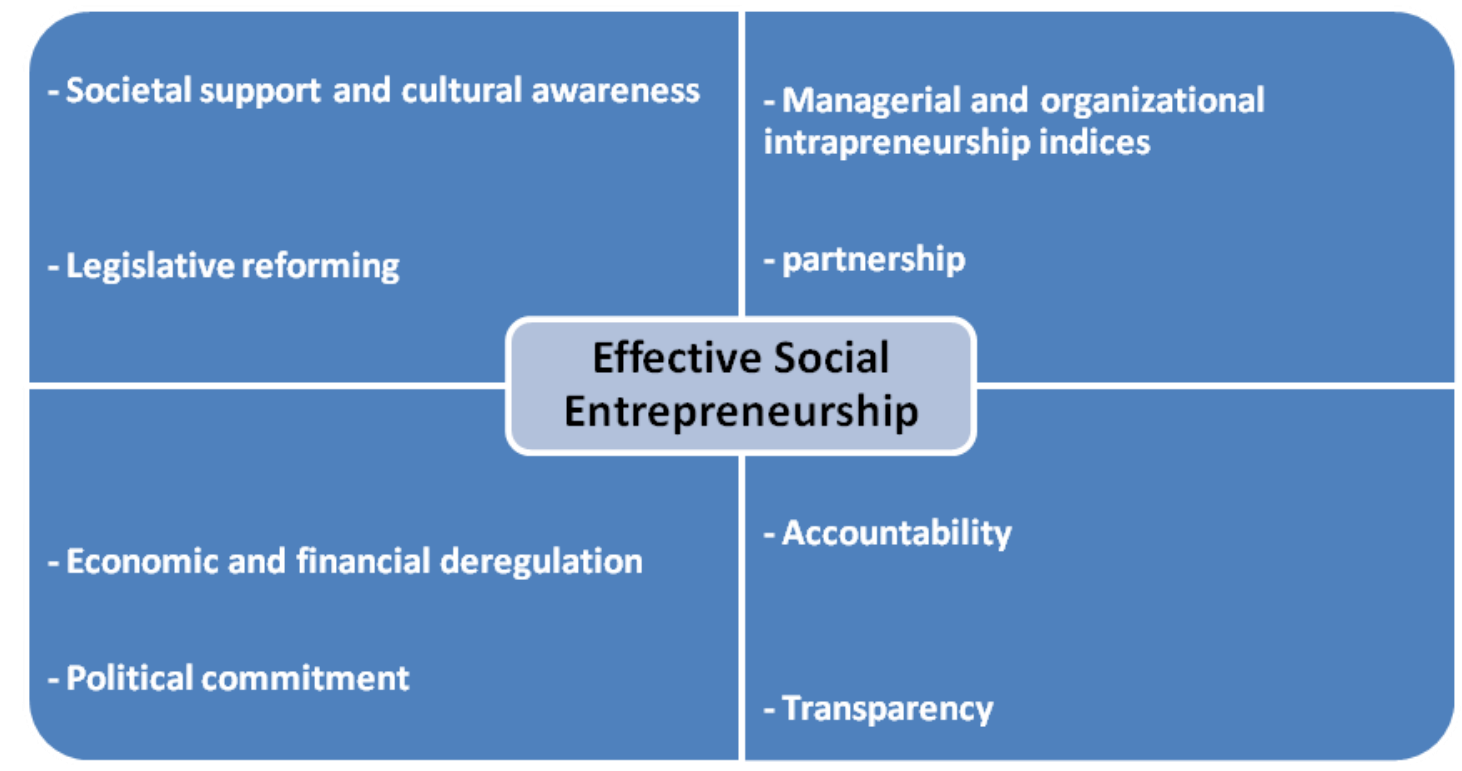

Fig. 2: Proposed remedy indices to confront the Egyptian waqf corporate problems

\subsection{Partnership}

In social development organizations, as waqf corporate in Egypt, awqaf apparatus that oversees the waqf corporate activities in Egypt; needs to be developed on collectively useful partnership relationships relied on trust among the many stakeholders involved in the social activities whether they are internal or external actors. On other words, it is important to encourage cooperation and collaboration to retrieve extraordinary types of thinking, 
innovation and creativity that respond to changeable community needs (Alpkan, L., \& others, 2010).

\subsection{Accountability}

Shaping accountability will have to take into accounts the nature of the partnerships in the entrepreneurship involvement. Where strong partnerships are there, an intrapreneurship method begins with mutual efficiency prospect, continues with mutual decision making process and yields ultimately to impart accountability (Bygrave, 1989). There is a requirement to authorize staff within the potential social entrepreneurship organization as Egyptian awqaf apparatus toward a shared vision. Members on this organization grow to be worried in surroundings, owning and realizing this imaginative and prescient vision. Responsibility is dispersed close to resolution making in order that humans are provoked to learn towards what they are detained accountable to do (El weeshey, 2002). Thus, it's central to bond the organization to its atmosphere. Participants are eased to see the effect of their work on the whole firm. As a result, they examine their surroundings and handle information to adjust work manifestations, and the organization is connected to its communities.

\subsection{Transparency}

Transparency is needed in defining the imperative roles and tasks of partners for the social entrepreneurship, and particularly the success of the intrapreneurship system (Alvord, S. H. \& others, 2002). Suitable revelation of the approaches used to share financial and administrative information regarding waqf corporate activities is primary to supply ongoing social entrepreneurship possibilities. In social entrepreneurship organizations as Egyptian awqaf apparatus, visibility is essential to impart trust among different social partners whether they are other social entrepreneurs or beneficiaries in the community, whereby sustainable cooperation are afforded for steady waqf corporate progress.

\section{5 Legislative reforming:}

Legislations that govern the waqf corporate activity in Egypt had to be reviewed and filtrated to avoid any persistent contradictions in the current law. Then, a new aggregated law that encompasses all the law amendments had to be issued; to ease and encourage the creation of corporate waqf, in the context of clear transparency, collaboration and accountability (Khoulousy, 2002).Moreover, to give them more discretion as independent entity, that can operate their activities beyond the central authority of the Egyptian awqaf apparatus. Therefore, its ability for responding speedily to community needs will be enhanced which will pave the way to become an effective social entrepreneur.

\subsection{Societal support and cultural awareness:}

Many media campaigns leaded by religious institutions, civil society organizations (as NGOs, syndicates, unions....) and even governmental agencies in Egypt had to be planned and performed to notify publics about Egyptian awqaf apparatus major role in managing various waqf corporate (Ameen, 1980).It is important to shed light on its progress objectives and its positive results on the community to make members and institutions within the society aware 
about pertinent waqf corporate activities and to be convinced about its important role to enhance the social entrepreneurship in the community. Accordingly, a supportive societal culture will be created and any societal resistance for waqf corporate adoption can also be evaded (El weeshey, 2002).

\subsection{Economical and financial deregulation}

It aims to create a public budget for Egyptian awqaf apparatus featured by visibility; restricting to modern accounting principles, clearly displayed and reliable for publics. Also, defects entailing private trustees and cash budgets had to be fixed. Moreover, it is important to invest the waqf corporate funds managed by awqaf apparatus economically in various profitable projects with minimum risk, via some qualified economical experts, to engender more financial resources necessary to enhance its social entrepreneurship role in the community (Omar, 2004; Zaqzouq, 2000).

\subsection{Political commitment}

The commitment of political leadership is needed to work as a leading force to build powerful networks of partners in a good governance context; to implement with ease the effective social entrepreneurship model within the community realizing its innovative social role; which is foremost for the economic and social progress of the society.

\section{7- Conclusion:}

We note after the previous analysis that Egyptian awqaf apparatus need to be deregulated and converted into an effective social entrepreneur, able to realize innovation, risk control and proactiveness. Then, it will pervade to different strata of the community responding effectively to their needs and fill the gap between the government declined performance and private sector citizen-exploited activities. This is a basic change whereby it will be able, via waqf corporate activities, to realize effectively its national plan for development and the outcomes/results of its developmental projects will be delivered to the poorest citizens in the country.

Accordingly, adopting the identified principles for effective social intrapreneurship is critical to create the intended social entrepreneurship organization; that can be able to maintain social welfare in the community. Such effectiveness principles can be briefed as: organizational and management support, effective visible administrative linkages (channels of communication), advocated organization culture, clear participative strategy and lean flat structure.

Unfortunately, there are diverse problems-as we aforementioned-that impede the conversion of the Egyptian awqaf apparatus into a key player to enhance social entrepreneurship in the community. Such challenges can be abbreviated as: Legal problems, managerial and organizational problems, economic and financial problems, Social and cultural problems and embedded corruption.

Consequently, in order to overcome the aforementioned problems it necessitates the adoption 
of various remedy indices relying on NPM principles, good governance indices and social intrapreneurship principles; such indices are: Managerial and organizational indices, partnership, accountability, transparency, legislative reforming, societal support and cultural awareness, economic and financial deregulation.

Finally, we assure hereby that the political commitment for such remedies indices is a must; whereby no reforming efforts can success - especially in developing countries as Egyptwithout the political leadership support and people awareness about the importance of this reform. The government had to acquire also the necessary financial and technical resources to enhance their reforming program. It can procure such various resources by local funding or by foreign international grants and donations programs.

\section{References:}

- Alpkan, L., Bulut, C., Gunday, G., Ulusoy, G. \&Kilic, K, Organizational support for intrapreneurship and its interaction with human capital to enhance innovative performance, Management Decision, 48 (5) ,2010, pp.732-755.

- Alvord, S. H., Brown, L. D., Letts, C. W..Social Entrepreneurship and Social Transformation: An Exploratory Study, Working Paper 15, Cambridge, 2002, pp. 26-28.

- Ameen, M, awqaf and social life in Egypt, Dar el nahda el Arabia, Cairo, 1980, pp. 18- 26.

- Anjavinejad, S. M., \&Emami, M., Changes in legislation and principles of Waqf to the new creation. Modares Human Sciences, 8(3), 2004, pp. 101-112.

- Antoncic, B. \&Hisrich, R.D., Corporate entrepreneurship contingencies and organizational wealth creation, Journal of Management Development, 23 (6), 2003, pp. 518-550.

- Antoncic, B. Organizational processes in intrapreneurship: a conceptual integration, Journal of Enterprising Culture, 9 (2), 2001, pp. 221-235.

- Austin, J., Stevenson, H., Wei-Skillern, J, Social and Commercial Entrepreneurship: Same, Different, or Both?, Entrepreneurship: Theory and Practice30, pp.1-22,2006.

- Barlett, D. \&Dibben, P., Public sector innovation and Entrepreneurship:

Case studies from local government. Local Government Studies, 28(4), 2002, pp.107-121.

- Birkenshaw, J., Entrepreneurship in the global firm, Sage, London, 2000, pp. 125-126

- Burgelman, R. A. Managing corporate entrepreneurship: New structures for implementing technological innovation, Technology In Society, 7, 1985, pp. 91-103.

- Bygrave, William D, The Entrepreneurship Paradigm (I): A Philosophical Look at Its Research Methodologies, Entrepreneurship Theory and Practice, Fall 1989, pp. 7-26.

- Chisholm, T.A., Intrapreneurship and bureaucracy, SAM Advanced Management

Journal, 52 (3), 1987, pp. 36-41. 
- Cunningham, J. Barton \&Lischeron, Joe, Defining Entrepreneurship. Journal of Small Business Management, Vol. 29, No. 1, 1991, pp. 45-61.

- Day, George S., Market Driven Strategy: Process for Creating Value. The Free Press: New York, 1990, pp. 61-69.

- Dees, J. G. Enterprising Nonprofits: What Do You Do when Traditional Sources of Funding Fall Short? Harvard Business Review, 1998, pp. 55-67.

- Diefenbach, F.E., Entrepreneurship in the public sector, When middle managers create public value, Gabler Verlag, Wiesbaden, 2011, pp. 53-59.

- Drucker, Peter F., Innovation and Entrepreneurship: Practice and Principle, London: Heinemann, 1985, pp. 50-51.

- El Weeshey Fathy A., Waqf legal framework in contemporary Islamic countries, General secretariat of awqaf, Kuwait, 2002, pp. 14-39.

- Engwall, M. \&Westling, G., Peripety in an R\&D drama: Capturing a turnaround in projects dynamics, Organization Studies, 25 (9), 2004, pp. 1557-1578.

- Fakhrul Anwar Zainol, Wan Norhayate Wan Daud, Zulhamri Abdullah \& Mohd Rafi Yaacob, Social Entrepreneurship Via Corporate Waqf: A Case of Islamic Chamber of Commerce (ICC) in Malaysia, global journal of commerce and management perspective.

Vol.3 (5), September-October 2014, pp. 50-53.

- Gliedt, T., \& Parker, P, Green Community Entrepreneurship: Creative Destruction in the Social Economy. International Journal of Social Economics, 34(8), 2007, pp. 538-553.

- Guth, William D. \&Ginsberg, Ari, Guest Editors’ Introduction: Corporate Entrepreneurship. Strategic Management Journal, Vol. 11, Summer Special Issue, 1990, pp. 5-15.

- Habibollah Salarzehi, Hamed Armesh \& Davoud Nikbin, Waqf as a Social Entrepreneurship Model in Islam, International Journal of Business and Management Vol. 5, No. 7; July 2010, pp. 179- 187.

- Heinonen, Jarna, Towards Customer Orientation and Competitiveness: The Potential of Intrapreneurship in the Change Process of a Municipal Service Unit) Publications of the Turku School of Economics and Business Administration Series A, 1999b, pp. 5-9.

- Kahf, M., Waqf and its Socio Political Aspects, 2002. [Online] Available:www.awqafsa.org.za/.../Waqf\%20\&\%20its\%20Socio\%20Political\%20Aspects\%20 $\%$ 20Monzer\%20Kahf.pdf.

- Kahf, M. Towards the revival of awqaf: A few issues to reconsider. Presented at the Harvard Forum on Islamic Finance and Economics, 1 October, 1999, Retrieved from Monzer.kahf.com

- Khoulousy. M. Khoulousley, problems confronting waqf corporate in Egypt, Saleh Kamel center for Islamic economy, Azhar University, October 2002, pp. 1- 28 


\section{I Macrothink}

Journal of Public Administration and Governance

ISSN 2161-7104

2016, Vol. 6, No. 4

- Krafess, J., The influence of the Muslim religion in humanitarian aid. International Review of the Red Cross, 87(858), 2005, pp. 327-342.

- Landström, Hans, The Roots of Entrepreneurship Research, Paper presented to the RENT XI Conference, November 26-27, 1998. Lyon, France, pp. 2-11.

- Larbi, George A., The New Public Management Approach and Crisis States, UNRISD Discussion Paper, No. 112, Geneva, Switzerland, 1999, pp. 2- 15.

- Löfström, M., Inter-organizational collaboration projects in the public sector: a balance between integration and demarcation, International Journal of Health Planning and Management, 25 (2), 2010, pp. 136-155.

- Lowndes, V., Something old, something new, something borrowed...How institutions change (and stay the same) in local governance, Policy Studies, 26 (3/4), 2005, pp. 291-309.

- Luchsinger, V. \&Bagby, R.D Entrepreneurship and intrapreneurship: Behaviors, comparisons, and contrasts, SAM Advanced Management Journal, 52 (3), 1987, pp. 10-14.

- MacMillan, Ian C., Progress in Research on Corporate Venturing, The Art and Science of Entrepreneurship, Ballinger: Cambridge, 1986, pp. 241-263.

- Mair, J., Marti, I. Social Entrepreneurship Research: A Source of Explanation, Prediction, and Delight, Journal of World Business,41, 2006, pp. 36-44.

- Miri, A., Social Entrepreneurship: a review of the political and social field. Knowledge management,19 (72), 2006.

- Molina, C. \& Callahan, J.L., Fostering organizational performance: The role of learning and intrapreneurship, Journal of European Industrial Training, 33 (5), 2009, pp. 388-400.

- Morris, M. H., Davis, D. L. \& Allen, J. W., Fostering corporate entrepreneurship: Cross-cultural comparisons of the importance of individualism versus collectivism, Journal of International Business Studies, 25 (1), 1994, pp.65-89.

- Noya, A., the Changing Boundaries of Social Enterprises, Paris: OECD, 2009, pp. 5-8.

- Omar Abd El Haleem, Waqf management experiment at Egypt, Round table around Islamic awqaf trustees applications, Qazan: Tatarstan republic, 2004, pp. 5-16.

- Osborne, David. and Ted, Gaebler, Reinventing Government: How the Entrepreneurial Spirit is Transforming the Public Sector, Reading, Mass: Edition Wesley, 1992, pp. 23-34.

- Pearce, John A., Robertson Kramer, Tracy \& Robbins, D. Keith, Effects of Managers' Entrepreneurial Behavior on Subordinates, Journal of Business Venturing, Vol. 12, No. 2, 1997, pp.147-160.

- Pinchot, G. \& Pellman, R. Intrapreneuring in action: A handbook for business innovation, Berett-Koehler, San Francisco, 1999, pp. 65-79.

- Pollitt, C., Modernizing the Management of the Public Services Sector: Between Crusade 


\section{Macrothink}

Journal of Public Administration and Governance ISSN 2161-7104 2016, Vol. 6, No. 4

and Catastrophe?" Paper Presented to the Administrative Development Agency, Helsinki, Finland, 1994, pp. 23-42.

- Raissouni, A., Islamic 'Waqf Endowment': Scope and implications, (A. B. Rabat, Trans.), Islamic educational, scientific, and cultural organization, 2001, ISESCO, www edition. Retrieved from http://www.isesco.org

- R. Lalitha S. Fernando, Entrepreneurship In Delivery Of Service In Public Sector Organization In Sri Lanka: Prospects For Administrative and Managerial Reforms, Workshop on Innovations in Governance and Public Service to Achieve a Harmonious Society Network of Asia-Pacific Schools and Institutes of Public Administration and Governance (NAPSIPAG) Annual Conference 2005, Beijing, PRC, 5-7 December 2005, pp. $1-26$.

- Sadeq, A. M., Waqf, perpetual charity and poverty alleviation, International Journal of Social Economics, 29(1/2), 2002, pp.135-151.

- Sadler, J. Corporate entrepreneurship in the public sector: The dance of the Chameleon, Australian Journal of Public Administration, 59 (2), 2000, pp. 25-43.

- Shane, Scott \&Venkataraman S., the promise of entrepreneurship as a field of research, Academy of Management Review, Vol. 25, No. 1, 2000, pp. 217-226.

- Slađana Brajević, Antonija Babić and Ivona Jukić, social entrepreneurship and economic development, 2nd Dubrovnik International Economic Meeting, 2015, pp. 177- 187.

- Sundin, E. \&Tillmar, M., A nurse and a civil servant changing institutions:

Entrepreneurial processes in different public sectors organizations, Scandinavian Journal of Management, 24, 2008, pp.113-124.

- Ulrika Westrup, Internal entrepreneurship in the public sector: the challenges of integrating innovative project into the regular organization, Scandinavian journal of public administration, 16(4), 2013, pp. 97-112

- Weerawardena, J., Investigating Social Entrepreneurship: A Multidimensional Model. Journal of World Business, 41(1), 2006, pp. 21-35.

- Wunderer, R., Employees as 'co-intrapreneurs' - a transformation concept, Leadership \& organization Development Journal, 22 (5), 2001, pp. 193-211.

- Zaqzouq, Hamdy. M, Egyptian awqaf, a paper presented to waqf workshop at charity Islamic association, Egypt, 2000, pp. 26- 43.

\section{Copyright Disclaimer}

Copyright for this article is retained by the author(s), with first publication rights granted to 
the journal.

This is an open-access article distributed under the terms and conditions of the Creative Commons Attribution license (http://creativecommons.org/licenses/by/3.0/). 